\title{
Industrial Policy and Tax Avoidance
}

\author{
Ruitao Xie \\ School of Management, Jinan University, Guangdong, China \\ Email: 13710348148@163.com
}

How to cite this paper: Xie, R.T. (2018) Industrial Policy and Tax Avoidance. American Journal of Industrial and Business Management, 8, 1476-1506. https://doi.org/10.4236/ajibm.2018.86100

Received: May 17, 2018

Accepted: June 11, 2018

Published: June 14, 2018

Copyright (C) 2018 by author and Scientific Research Publishing Inc. This work is licensed under the Creative Commons Attribution International License (CC BY 4.0).

http://creativecommons.org/licenses/by/4.0/

\begin{abstract}
Since the past three decades, China's economy has been growing rapidly. The impact of the rapid development of China's economy is inseparable from the government, who intervenes in the economic life through laws, policies, regulations, etc. As a way of intervention by the government, the promulgation and implementation of policies have certain purposes. In the capital market, the government changes the financing constraints of companies through the implementation of industrial policies, thus changing their tax avoidance behaviors. This paper selects the listed companies in Shanghai and Shenzhen during the Tenth Five-Year Plan and the Twelfth Five-Year Plan of National Economy and Social Development as the sample to analyze the influence of Chinese industrial policy on the tax avoidance behavior of enterprises and their internal mechanism. Our study finds that firms that are supported by industrial policies have been able to ease their financial constraints and have a lower degree of tax avoidance than those that are not supported by industrial policies. Further analysis finds that the above phenomenon is more pronounced in the non-state-owned enterprises and the regions with weaker tax enforcement. Our study not only enriches the academic literature on the microscopic mechanism of industrial policy, but also provides new empirical evidence on the factors of corporate tax avoidance.
\end{abstract}

\section{Keywords}

Industrial Policies, Tax Avoidance, Financial Constraints, Five-Year Plan, Ownership Type, Tax Enforcement

\section{Introduction}

\subsection{Research Background}

Since China's reform and opening up in the 1980s, China's economic system has gradually transformed from a planned economy to a market economy. Different from the capital markets of developed countries in the West, in the process of 
economic restructuring, Chinese companies have different institutional backgrounds. When companies face financing decisions, they are affected by the macro industrial policies of their country to varying degrees. China is one of the countries in the global economy that uses most industrial policies. Scientifically formulating and implementing industrial policies will inevitably have a huge impact on economic development. Since the reform and opening up in the last century, China's central government and local governments at all levels have introduced one or more industrial economic incentive measures, which has made China's economy develop by leaps and bounds. The most typical of these is the government's measures during the 2008-2009. In response to the impact of the global financial crisis, the Chinese government has boldly launched ten major projects to revitalize industrial economic development. The government's four trillion fiscal stimulus plan and industrial revitalization plan have had a huge impact on the macro economy. What industries have been included in the top ten industries has once been the focus of attention. As the maker of industrial policies, the government plays an important role in emerging market economies. Taking into account the special economic transformation process in China, the role of the government in the economic life of the entire country cannot be ignored. In fact, Japan, the United States, the European Union and other developed market economies have all introduced a large number of industrial policies in the promotion of national industrial development, and have achieved recognized results. In particular, in recent years, the United States has advanced the "Advanced Manufacturing Partner Program" and "Advanced Manufacturing Country Strategic Plan"; Japan has implemented the "New Japan Motor Vehicle Strategy" and "Japan's New Robot Strategy"; and Germany has issued "About Implementation of Industry". The "Strategic Recommendations of 4.0" and so on are also concrete manifestations of the government's use of industrial policies to promote microeconomic individual development. The adjustment of industrial policy in the United States in the 1990s has yielded great results. The following points have been expressed: 1) the state has stepped up its efforts to intervene in industrial development, and in particular, the Clinton administration's intervention in the industry is unprecedented. The Clinton administration's intervention in the industry can be divided into internal interventions in the industry and external interventions in the industry. The internal intervention of the industry is mainly to adopt a series of industrial technology policies, starting with technological innovation and technological development, and increasing support for the industry. Its outstanding performance is that the Clinton Administration has formulated a series of medium and long-term scientific and technological development plans. The most famous one is the "Information Highway" plan, which has a certain "plan" color. There are two forms of intervention outside the industry. One is to intervene in foreign trade, and to create conditions for the development of the industry by exploiting the international market and protecting the domestic market; the second is to intervene in the capital market and provide sufficient funds for industrial development. 2) The 
direct government intervention is limited. In addition to direct intervention in industrial technology development, other policies are mostly indirect or non-administrative. For example, to intervene in industrial organizations within the scope of the law, but the starting point of the intervention is to improve or maintain the international competitiveness of US industries. On this basis, the government maintains the tradition of "maintaining free competition" and the Clinton Administration's flexible industrial organization policy. It not only safeguards the competitiveness of industries that have a monopoly in the world, but also promotes innovation in these industries. It also allows other industries in the country to take advantage of economies of scale and actively participate in global monopolistic competition. Because of this, many economists believe that US industrial policy is hidden. 3) Making full use of the U.S. status in the international trade and financial system and possessing the international political and military superpower status, political, military, and economical means cooperate with each other, and make every effort to increase the U.S. industry's international competitiveness and its policies. The implementation of the tool is global, and it is not only focused on the United States. 4) The formulation and implementation of U.S. industrial policy conforms to the realities of the United States. The Cold War junta industry consumed a large amount of U.S. resources, seriously affected the development of civilian industries, and even jeopardized the international competitiveness of the industry. However, it also enabled the U.S. to possess the most advanced military technologies in the world today. These military and information technologies, new material technologies and the aerospace technology is closely related. After transformation, it can provide strong technical support for the development of the US high-tech industry. The Clinton Administration's industrial policy is based on industrial technology policy as the core of the industrial policies. It not only meets the needs of the development of high-tech industries, but also in line with the United States.

The government can influence individual behavior through the formulation of industrial policies. The formulation of a policy is the result of the fight between different interest groups. Different interest groups lobby government agencies or legislators in an attempt to obtain maximum benefits. Many US small and medium-sized groups may even form alliances of interest to lobby legislators to gain policy support; there are also some companies in the industry that form industry alliances that assemble the strength of the entire industry to test pressure on policy makers to form industry advantages. For example, through the actions of interest groups, industry will encourage the introduction of policies, industry tax incentives and tax returns, government subsidies, industry credit rationing and other advantages also followed. Therefore, the industry's capital costs and financing constraints have been changed, and thus affect the company's individual tax avoidance.

\subsection{Research Motivation}

As China's economic development entered a new normal state, macro-control 
has become more difficult. That is why the government must continue to introduce innovative control ideas and control measures to ensure that the implementation of macro-industry policies is more timely, effective and accurate. China is one of the countries with strong industrial policies in the world. Industrial policies play an important role in China's economic restructuring and industrial modernization. Therefore, ensuring that industrial policies are accurately and effectively implemented is extremely important in China today. Clearly clarifying the resources allocation function of industrial policies has a very important significance for China's economic transition and economic system reform under the new normal state.

Industrial policy is a policy system that the government uses economic, administrative, and legal methods to regulate, guide, and intervene in specific industries based on their own economic conditions, especially the trends and current state of industrial development. The government's intervention in the economy can be said to be the essence and core of industrial policy. A mainstream view of industrial policy_ "market shortage theory" says that the failure to make up for the market is the main reason of the implementation of industrial policy and the government's intervention and regulation of the economy can play the market's functions more effectively. The "market failure" theory of neo-classical economics regards the non-optimal allocation of resources caused by the actual market different from the ideal market type as the basis for implementing industrial policies. Due to asymmetric information and economic externalities, the government can play the role of correcting market failure. The government can not only play a role in the innovation and improvement of the system, but also can identify market failures in the development of the industry and further adopt administrative measures to correct market failures. The externality of information is one of the causes of market failure. The government can compensate for the cost of innovation and encourage a company to innovate through a subsidy policy. It is a compensation for the cost of antecedent enterprises or industries. Another factor in market failure is the coordination issue. The government can play a guiding and coordinating role in the public domain in education, finance, legal systems, and infrastructure, and create a good institutional environment for industrial development.

On the other hand, in China, due to the lack of institutional arrangements during the transition period and the inefficient implementation and enforcement of industrial policies, corporate tax avoidance is more common. Take corporate income tax as an example. Although the statutory income tax rate in China is $25 \%$, the average tax rate of listed companies in Shenzhen and Shanghai in 2015 was only $10.5 \%$. Even if companies with tax incentives are removed, the listed company's income tax burden will be much lower than $25 \%$.

Therefore, if we want to explore whether the allocation of industrial policy resources works well, the tax avoidance level of enterprises is a good perspective. When a country interferes with a specific industry, it will indirectly affect the fi- 
nancing structure and economic behavior of the company.

This article attempts to examine and explore the impact of industrial policy on the tax avoidance behavior of listed companies in China, and combines theoretical and empirical research conclusions to make recommendations on the formulation and implementation of China's industrial policies.

\subsection{Significance}

1) Theoretical significance:

Our study can enrich relevant literature in our country's academic circles. Moreover, the purpose of industrial policy implementation is to directly or indirectly influence the behavior of microeconomic entities through certain means, so as to achieve the purpose of policy formulation. Although the current theoretical circle has not reached a unified opinion on the necessity of the formulation and implementation of industrial policies, many scholars at home and abroad have learned different research samples and research methods and come to the same or different conclusions. However, various countries and governments around the world are formulating and implementing relevant policies, even if it is a Western developed capitalist country that promotes the market's omnipotence. The period in which the government frequently formulates industrial policies is often the time when social and economic operations are at issue. The stimulus package implemented by the government after the global financial crisis in 2008 clearly confirms this.

Based on the theory of predecessors, this paper studies the influence of industrial policies on tax avoidance of listed companies, which enriches the related theories of industrial policies and micro-firm behaviors in the context of China's system, and provides certain empirical evidence for the effectiveness of industrial policies.

2) Practical significance:

Whether the research company's tax avoidance behavior will be affected by industrial policies can be related to whether there is a link between industrial policies and corporate tax avoidance, so as to provide relevant reference for relevant parties. For example, if there is a negative correlation, that is, compared with industries and companies that are not supported by industrial policies, industries and companies encouraged by industrial policies are less tax avoidance, so that it may be necessary for the government to increase the tax collection and management of industries supporting non-industry policies. It can also provide basis for investors, or analysts to analyze the company's real financial situation.

\subsection{Possible Innovations}

First, based on the theory of predecessors' research, this paper studies the impact of industrial policies on tax avoidance of listed companies and enriches the related theories of industrial policies and micro-firm behaviors in the context of China's system. 
Second, the research results of this article can enrich and improve the relevant literature on the factors of corporate tax avoidance in the context of China's system. This aspect can provide a new perspective for analyzing the causes of tax avoidance in our country; on the other hand, it also provides new ideas for analyzing the effect of industrial policy implementation.

\section{Conceptual Definition and Literature Review}

\subsection{Conceptual Definition}

\subsubsection{Industrial Policy}

The idea of industrial policy has a long history and can be traced back to 17th century Britain's trade and industrial protection policies. Later, in the United States, Germany, and other countries, they imposed import taxes to protect domestic infant industries and protect and foster national industries. However, until the 1950s, the term "industrial policy" was formally proposed by the Japanese academic community. Nowadays, it is a widely used economic term. However, there are different perspectives on the understanding and research of industrial policies. There is no accurate definition of industrial policy in the theoretical circle in China. Some scholars have pointed out that a broad industrial policy refers to the sum of all policies that a country or a government uses to regulate and control the economy for a particular industry, while a narrow sense of industrial policy refers to the directive of a department that regulates or guides and promotes industrial restructuring. There are also scholars who define the industrial policy from another perspective. They think that the broad industrial policy should be the sum of all the policies introduced by the government for the industry. When problems occur in the socio-economic operation, the government acts as a "visible hand" to make up for market deficiencies. Another concept of industrial policy that is more commonly used is the industry's catch-up policy. This definition is most often seen in East Asia, especially Japan. The related research on the latecomer advantage of industrial development in countries such as Korea and South Korea mainly refers to the sum total of policies formulated when a country's industrial economy is lagging behind or may lag behind other countries in order to advance its industrial restructuring and strengthen its industrial development.

In short, from the perspective of different researches, the definition and scope of industrial policies are somewhat different. However, the same point is that industrial policies are targeted at the industry and achieve the policy objectives through the role of the relevant industries. China's industrial policies rarely reflect the form of legislation. Most of them appear in other forms, such as "decision" and "planning". One of the reasons may be that Chinese state-owned enterprises occupy an important position in the entire economy and occupy an absolute dominant position in the special industries related to the national economy and the people's livelihood. The implementation of industrial policies can be achieved by means of support, encouragement, or regulation. 
The industrial policy study of this article is considered from the perspective of the government's overall policy on the introduction of industries, and refers to the tenth, eleventh, and twelfth five-year plans for national economic and social development.

\subsubsection{Corporate Tax Avoidance}

Tax avoidance generally means that the taxpayer adopts the legal means to make use of the existing problems and loopholes in the tax law to minimize the tax burden on taxpayers by carefully arranging production operations and financial planning. Generally speaking, the definitions of tax avoidance at home and abroad are basically the same. They all agree that tax avoidance is based on familiarity with the tax law, use of loopholes or weaknesses in the tax law, and arranging tax-related matters, thereby reducing the taxpayer's tax burden. Tax avoidance does not infringe criminal law. However, tax avoidance is an act that can be considered shameful and even attracts the attention of tax authorities and lending institutions.

Nowadays, scholars in many countries agree that tax avoidance is the result of misuse of the tax law, and that taxpayers perform human financial planning, use weaknesses and loopholes in current tax laws and regulations, and reduce their own tax burden. The reduction of government revenue is the ultimate consequence of corporate tax avoidance. As a result, most of the measures adopted by governments of various countries to avoid taxation are gradually improving the tax law, revising loopholes in the tax law, and strengthening the collection and management of specific companies. This can reduce the degree of tax avoidance of enterprises to a certain extent, but it is generally impossible to use legal means to punish taxpayers' tax avoidance behavior. According to China's current situation, tax avoidance is no longer considered a neutral means, but is an illegal act prohibited by the laws and regulations in our country.

As far as China is concerned, compared with other taxes, the income tax rate is obviously higher, and the taxpayer's tax payable is extremely close to the company's accounting, and the calculation is also particularly complicated, involving the data of various reports, and thus the income tax. It will generally become the focus of the company's tax planning. Therefore, this article focuses on examining corporate income tax avoidance.

\subsection{Literature Review}

\subsubsection{Literature Review of Industrial Policy and Micro Business Behavior}

Nowadays, the correlation between macroeconomic policy and micro-enterprise behavior has become an important hot spot in the current economic and financial fields. The existing related articles mainly discuss the impact of macroeconomic policies on the financial behavior of microscopic individuals.

Industrial policy is one of the macroeconomic policies promoted by the government. Its implementation and implementation will affect the microscopic in- 
dividual's financial behavior and economic output. The output of micro-enterprises is an integral part of economic output. Macroeconomic policies adjust micro-enterprises' behavior to reach a certain goal (Rao Pingui et al., 2013) [1]. Therefore, studying the impact of macro-industry policies on micro-firm behaviors is more conducive to understanding the purpose of implementing industrial policies and improving industrial policies. The existing literature discusses the impact of macro-industry policies on micro-enterprise behavior from multiple perspectives.

Bergstorm (2000) [2] studied the Swedish government's data on financial subsidies to enterprises. The empirical results show that government subsidies affect the company's performance. Government subsidies can improve the company's performance in the first year, but will be used in the following years. The performance of the company has a negative impact. The study of Aghion et al. (2015) [3] found that industrial policies can promote competition among large and medium-sized enterprises and encourage the development of enterprises with high initial and productive efficiency.

Domestic studies in this area mostly focus on industrial policy research on corporate finance, investment, innovation, and performance. Chen Donghua (2010) [4] empirically analyzes the mechanism of industrial policy on micro-enterprises' individual financing. The results show that enterprises that are supported by industrial policies have higher equity refinancing than those that are not supported by industrial policies; enterprises that are supported by industrial policies, The amount of long-term borrowings is significantly higher than that of enterprises that are not supported by industrial policies, but the amount of short-term bank borrowings has the opposite result. Li Wenjing (2014) [5] studied the impact of industrial policies on corporate investment behaviors according to the nature of property rights. His research results show that private enterprises supported by industrial policies are more likely to break through the barriers to industry barriers, so that they can obtain more financing and then invest. Increased, but because of blind investment, investment efficiency is reduced. This result was not significant in the SOEs. Li Wenjing and Zheng Manni (2016) [6] conducted research and analysis on the impact of China's industrial policies on corporate innovation behavior. The study's conclusions show that enterprises that are supported by industrial policies have significantly higher patent applications than those that are not supported by industrial policies. However, this is only a non-invention. The significant increase in patents shows that companies supported by industrial policies only pursue "quantity" and ignore "quality"; they also found that if companies expect to receive government subsidies and tax incentives, their patent applications, especially non-invention patent applications, will be significant. The increase indicates that the fiscal and taxation policies in the selective industrial policies have driven companies to carry out innovation activities for "finding support and support".

In addition, some scholars explore the impact of macro-industry policies on 
micro-firm behaviors from the perspectives of investor behavior, managerial overconfidence, and bank correlation. Han Qian (2014) [7] studied how margin financing prices and investor behavior were affected by the country's emerging strategic industrial policy. Their research results show that investors can obtain relatively high excess returns in the short term after the announcement of the industrial policy, but this result did not have significant results in the medium and long term after the announcement. They believe that the reason for this phenomenon is that during the period of continuous disclosure of industrial policies, institutional investors took advantage of their own information to carry out arbitrage, further leading to the failure to raise the prices of related securities. The research of Bi Xiaofang et al. (2015) [8] found that if industrial policy and its transmission mechanism convey excessively aggressive policy signals, it will lead to managers' continuous overconfidence, thus distorting their views on resource allocation, and ultimately intensifying the liquidity risk of enterprises. Zhu Jigao (2015) [9] also discovered that industrial policy is one of the most important factors affecting companies' banking linkages. They found that companies that are not supported by industrial policies are more likely to associate with banks than those that are supported by industrial policies. From the opposite point of view, companies that are supported by industrial policies should obviously be more easily financed.

This group of documents based on a micro-level analysis focuses on the allocation of industrial policy resources and corporate investment and financing. These measures affect the short-term structure of enterprises, which shows that industrial policies have the effect of accelerating economic development. The tax avoidance of enterprises is also related to the company's performance and survival, and even the overall taxation of a country. If the implementation of industrial policies is examined from the perspective of corporate tax avoidance, it can provide some evidence for the financial supervisory authorities. At present, the content of this part of the literature in our country is still relatively small, so it is worth studying this aspect in depth.

\subsubsection{Literature Review of Factors Affecting Corporate Tax Avoidance}

Another set of literature related to the research content of this article focuses on various factors that affect corporate tax avoidance. There are many existing researches on the influencing factors of corporate tax avoidance. A large number of literatures regard tax avoidance as an important corporate strategy and examine various factors affecting tax avoidance activities.

The group of documents on the factors affecting corporate tax avoidance can be roughly divided into two categories. One type focuses on the influencing factors of tax avoidance from the perspective of internal factors. Based on the political rights hypothesis, Porcano (1986) [10] found that the larger the size of a firm, the greater its ability to control the political process, and the more likely it is to use its ability to conduct tax planning or earnings management to reduce tax burdens. The conclusions of two scholars, Wang Yuetang (2009) [11] and Li 
Zengfu (2010) [12], also show that the scale of the company has a positive impact on the earnings management of the company. Defond (1994) [13] cuts in from the perspective of debt level and his empirical research finds that the higher the debt level, the higher the level of earnings management. This shows that companies do not choose to avoid tax due to the cost of debt coven Earnings management. The research results of Chinese scholar Li Zengfu (2010) [12] confirm the conclusion of Defond that the company's debt level is positively correlated with the degree of tax avoidance. Desai and Dharmapala (2006) [14] believe that corporate governance is another factor affecting corporate tax avoidance. Whether a company can properly solve the principal-agent problem depends on the level of corporate governance. Corporate governance is also at the same time incentives for managers and corporate tax avoidance. There is a moderating effect between them. Dyreng (2009) [15] discusses the factors of corporate tax avoidance based on behavioral economics. His research results show that there is a significant relationship between corporate tax avoidance and managerial individual effects. Edwards et al. (2016) [16] studied the effect of financing constraints on corporate tax avoidance. They pioneered the construction of macro indicators and micro indicators to measure financial constraints. As a result, it was found that when companies faced greater financial constraints, companies were more likely to implement tax avoidance activities. That is, the level of financing constraints that enterprises faced was negatively related to the level of corporate tax avoidance. .

Another set of literature focuses on the factors that influence the external environment that companies face. Cai and Liu (2009) [17] pointed out that market competition will strengthen the company's tax avoidance motives, and companies that are relatively disadvantaged in the competition have stronger tax avoidance motives. T Beck and C Lin et al. (2014) [18] discuss corporate tax avoidance from the perspective of information sharing and financial deepening. Crocker and Slemrod (2005) [19] found that the salaries of tax officials have significant correlations with the implementation policies of local taxation authorities and the strength of tax collection and management when they study the salary contracts of tax officials; Atwood et al. (2010) [20] Research results based on cross-country data show that corporate taxation is closely related to the national taxation system. Especially in those countries that demand "consistent taxation," global taxation, and strong tax administration, companies' tax incentives are even less. Fan Ziying and Tian Binbin (2013) [21], based on the background of China's income tax sharing reform, conclude that one of the reasons for large-scale tax avoidance by enterprises is that local tax authorities do not collect corporate tax revenue and enforce law enforcement. Wang Liangliang's (2016) [22] empirical test found that during the economic crisis, due to the deterioration of the external financing environment, the company was faced with higher financing constraints and strengthened the incentives for enterprises to carry out tax avoidance activities; compared with companies that were not subject to fi- 
nancing constraints, the companies were subject to financing constraints. During the economic crisis, the degree of tax avoidance has increased even more; in addition, if the financial marketization level of the company's region is higher, the economic crisis will have a weaker effect on the tax avoidance of the company.

Based on the above two sets of literature, it can be noted that there are still some deficiencies in the current literature. First, the current research literature on the impact of industrial policies on micro-firm behavior has focused mainly on topics such as the relationship between industrial policy and financing, investment and innovation, and the lack of attention to corporate taxation. Secondly, from the research literature on the macro environmental factors that affect corporate tax avoidance, the macro environmental factors that are currently being studied are more concentrated in the economic crisis, taxation system reform, fiscal and taxation policies, tax collection and management policies, lack of inspection of industrial policies. Third, it can be noted that the macro-enforcement effect of macroeconomic policies is the focus of most literatures examining macroeconomic policies and micro-enterprise behavior.

Therefore, examining the effectiveness of China's industrial policies from the micro perspective of corporate tax avoidance is conducive to enriching and expanding research on macroeconomic policies and micro-enterprise behavior.

\section{Theoretical Basis}

\section{Effective Tax Planning Theory}

According to the theory of effective tax planning, taxation is one of the company's operating costs. Although the tax avoidance activities of enterprises reduce their own tax burden, it also causes other transaction costs to increase. Therefore, the reduction of corporate paid tax does not mean that the company's after-tax income increases. That is to say, the minimum tax burden does not mean that the after-tax return is maximized. Scholes and Wolfson believe that when companies conduct investment and financing activities, they not only need to consider explicit tax costs, but also need to consider hidden non-tax costs. Among them, the non-tax cost refers to the transaction costs other than taxation brought about by the reduction of taxation costs when the company conducts tax avoidance activities. Information costs, political costs, financial reporting costs, and agency costs are common forms of non-tax costs. The cost of financial reports means that the increase in tax avoidance will lead to a decrease in book profits. The decline in book profits will further lead to a decrease in the market value of enterprises. Enterprises will face higher financing constraints and be more easily acquired. Political costs mean that companies need to obtain tax incentives through political lobbying and negotiation, or they can cooperate with government agencies to evade taxes to reduce tax burdens. The cost of information refers to the cost of hiring special tax personnel and entrusting professional taxation agencies so that they can become more familiar with tax policies and 
obtain reasonable tax planning plans. The agency cost means that the company's managers are disadvantaged for reducing the tax cost of the company. For example, in the case of asymmetric information, corporate shareholders generally measure the management's performance based on book profits. The decline in book profits thus leads to a drop in management income; similarly, book profits may also help senior executives to get promoted. For the top managers of state-owned enterprises, they may even affect their careers.

\section{Theoretical Analysis and Research Assumptions}

The first part of the second chapter mainly elaborates and summarizes the meaning of industrial policy and corporate tax avoidance. In the second part, we review and sort out the literature on industrial policy and corporate tax avoidance. The third part reviews the previous section of the literature. The theoretical basis believes that the implementation of industrial policies will indeed bring about a certain influence on the financing constraints of listed companies. Can the implementation of industrial policies affect the tax avoidance of companies?

\subsection{Industrial Policy and Corporate Tax Avoidance}

According to the rational economic man hypothesis, as a rational economic man, the goal pursued by the enterprise is to maximize its own interests, that is, to maximize corporate profits. Therefore, companies will weigh the costs and benefits of tax avoidance when choosing whether or not to avoid taxation.

The credit ration theory believes that under the condition of asymmetric information, the financing capacity of an enterprise will be affected by changes in macroeconomic factors in addition to its own factors such as asset-liability ratio. Industrial policy is a type of macroeconomic factor. Affect the company's financing decisions. The market's expectation of industry or industry can affect the company's financing costs and financing behavior. The announcement of an industrial policy of the government will cause the market's expectations of the industry to change. This expectation will affect the company's asset-liability ratio through the stock price and thus affect the company's financing costs and investment decisions, investment through the financial statements affect the company's financial structure, thereby affecting the company's financing decisions; The government can influence the IPO financing behavior of listed companies through the approval method. For companies that have already listed, government-led industrial policies can affect the company's external and internal financing costs through tax rates and other factors, resulting in a structural change in the company's financing constraints, thereby affecting the financing behavior of listed companies.

Therefore, it can be concluded from the credit rationing theory that changes in the macroeconomic variables have an impact on the company's financing decisions. Encouraging industrial policies can change the company's financing costs and financing constraints, and affect the financing behavior of listed com- 
panies. In order to achieve the development goals in the "Five-Year Plan", the government will generally relax the qualifications for bank credit approval, stock market listing, and refinancing in support of industry companies, and direct a large amount of resources to the supported industries, thus alleviating the company's financing constraints. Chen Donghua et al. (2010) [4] found that the IPO financing amount, equity refinancing opportunities and long-term loans of enterprises supported by industrial policies are significantly higher than those of other industries.

Taxation is one of the company's various economic expenditures. When a company can hold part of its tax revenue in the company rather than paying it to the tax authorities, the amount of internal funds held by it obviously increases, so it can use this part of funds for investment, production and other activities. To achieve this purpose, management can pay high consulting fees by borrowing debts through transfer pricing methods and high capital costs.

The research results of Cai and Liu (2009) [17] show that the more fierce market competition is, the stronger the tax incentives of companies, and the implementation of tax avoidance are. As a result, in the face of increasingly fierce market competition, most companies are under external pressure, so reducing taxes is an important means of maintaining profitability. Obviously, as a means for companies to increase disposable funds, tax avoidance is often used by companies. When the company is in a fierce market environment, reducing one dollar of tax expenditure will increase one dollar of disposable funds. Enterprises can use this part of funds for investment, $\mathrm{R} \& \mathrm{D}$, and expansion of reproduction. This will undoubtedly increase the competitiveness of the company. Therefore, the more fierce market conditions companies faced with, the more disadvantaged they are, the less profitable they are, their tax incentives are also stronger. Edwards et al. (2016) [16] examined the impact of financing constraints on corporate tax avoidance and found that the greater the financing constraints the firm faces, the higher its tax avoidance level.

Based on the above analysis, tax avoidance is an alternative to other financing methods adopted by companies when they are faced with financing constraints. Therefore, when the company's financing constraints are eased, the level of corporate tax avoidance should be significantly reduced. Specifically, the analysis can be expanded from the following two aspects: First, industrial policies have reduced the financing constraints faced by enterprises and reduced the marginal benefits of tax avoidance. This is because it becomes easier for companies to obtain external financing, and financing costs become lower. Under the condition that the corporate tax avoidance unit income and unit cost are unchanged, the marginal revenue of the company to obtain funds through tax avoidance will obviously be reduced. On the other hand, according to the theory of effective tax planning, although tax avoidance will bring potential benefits to enterprises and management, tax avoidance may be accompanied by corresponding direct and indirect costs (Hanlon and Slemrod, 2009) [23] [24]. Direct costs include fees 
paid to tax planning agencies, tax officials, and fees paid to auditors (Badertscher et al., 2013) [25]. Indirect costs, once tax avoidance is discovered, are severely punished by the tax authorities and not only cannot be obtained. Instead, the benefits are to pay more cash flow, and may enter the blacklist of tax authorities. The reputation of the company is corrupted and strictly regulated by the tax authorities. The future tax avoidance will be more difficult (Hanlon and Slemrod, 2009) [23] [24]. Obviously, the greater the possibility that enterprises can obtain foreign financing through industrial policies, the lower the financing constraints companies face and the smaller the marginal revenues for companies to avoid tax. The conceptual explanation is as follows (Figure 1).

Therefore, industrial policies have eased financing constraints for companies in certain industries, reduced the tax incentives of these enterprises, and reduced their tax avoidance. Based on the above analysis, this paper proposes Hypothesis 1:

$\mathrm{H1}$ : Under the same conditions, enterprises that are supported by industrial policies have lower tax avoidance than those that are not supported by industrial policies.

\subsection{Impact of Industrial Policies on Tax Evasion by Enterprises with Different Property Rights}

China is a country with a special institutional background. Under different ownership, there are many differences between the operating models of state-owned and private enterprises. State-owned enterprises can be seen as an institutional arrangement for the government to influence the economy. State-owned stocks alone create conditions for government intervention. State-owned enterprises have the phenomenon of unclear property rights, separation of government and enterprises, and excessive social responsibilities. The business objectives are diversified. The government that controls the power has the motivation to intervene in the company's business activities in order to achieve social stability, economic development, employment, taxation and other multiple policy objectives. However, its policy burden will affect its own benefit. The diversified business philosophy of state-owned enterprises not only increases their own operating costs, but also consumes their own resources. Excessive and inappropriate policy objectives also make the state-owned enterprises'

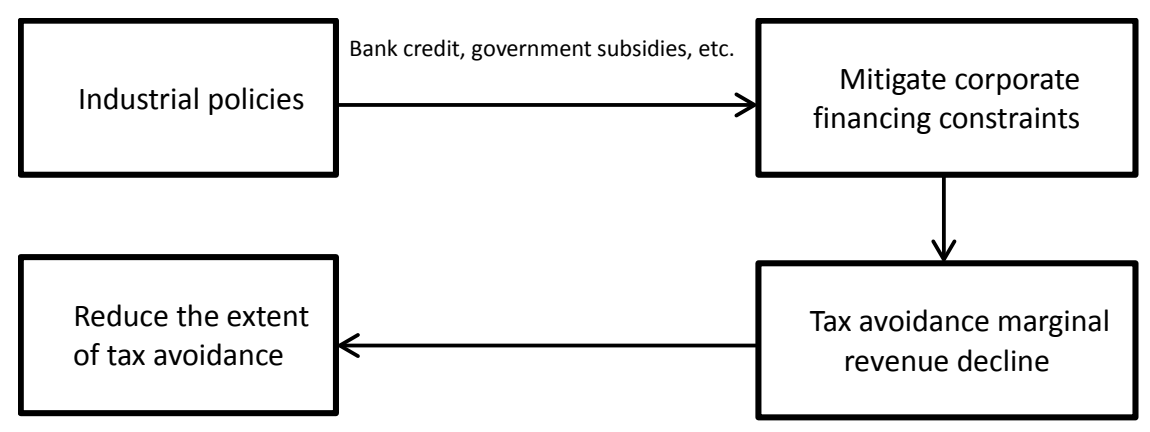

Figure 1. Impact of industrial policies on corporate tax avoidance. 
investment efficiency and production efficiency greatly reduced, even lead to losses, and the government must then rescue these loss-making state-owned enterprises and thus fall into a vicious cycle. From the above analysis, it can be seen that compared with private enterprises, state-owned enterprises are more likely to experience investment inefficiencies, but they are also more inclined to receive government subsidies to cause excessive investment.

Separation of ownership and management rights is an important feature of today's business. According to the principal-agent theory, the managers of a company may use their own status and use covert tax avoidance measures to cover up the real profits of the company for the purpose of self-interest, so that the loss-making items are maintained, which undoubtedly impairs the realities of the company's value. The existence of two different types of state-owned enterprises and private enterprises provides a unique sample and research perspective for the study of industrial policy and corporate tax avoidance.

From the point of view of non-state-owned enterprises, their ownership and management rights are not completely separated. The income and costs incurred by corporate management in tax avoidance activities are closely related to corporate management. Therefore, when the marginal revenue of tax avoidance is greater than zero, the company is likely to carry out tax avoidance activities. From the perspective of state-owned enterprises, on the one hand, corporate management cares more about their own salaries, positions, and careers. Due to its own policy objectives, the management of state-owned enterprises does not seek for success but seeks no success. This also makes it possible for management to conduct tax planning to cover up the company's true financial information. This undoubtedly also damages the value of the company. On the other hand, due to the complete separation of ownership and management rights, the interests of the management of state-owned enterprises are inconsistent with the interests of enterprises. Under the premise of no incentive mechanism, the tax-evasion motivation is likely to be weak. Moreover, paying a large amount of taxes to the state also reflects the contribution made by state-owned enterprises in responding to the state's finances, indicating that their operating performance is good and is conducive to maintaining the image of management in the eyes of the government. Therefore, the tax incentives of state-owned enterprises are influenced by two diametrically opposed factors.

Thus, from the perspective of the political relations owned by state-owned enterprises, it is naturally easy to obtain the support of the government, and thus the effect of industrial policy incentives is not obvious. Most of the existing research shows that for non-state-owned enterprises, compared to state-owned enterprises, due to the lack of political relations, it is even more difficult to obtain support from bank credit and higher industry barriers. Thus, when industrial policy supports a certain industry, private enterprises are affected more than state-owned enterprises. Based on the above analysis, this paper proposes hypothesis 2: 
$\mathrm{H} 2$ : Under the same conditions, in non-state-owned enterprises, the impact of industrial policies on the tax avoidance of enterprises is even more significant.

\subsection{Impact of Industrial Policies on Tax Evasion in Regional Enterprises with Different Tax Collection and Administration Strengths}

In order to ensure the taxation authority's taxation rights are implemented, China has formulated the "Taxation Administration Law". The so-called tax collection and management refers to an administrative activity in which the tax authority organizes and warehouses the amount of tax payable by the taxpayer in accordance with relevant national laws and regulations, in accordance with uniform standards and procedures, and the state implements the tax laws and policies to each tax payment. Obligors, a series of activities that effectively organize tax revenues and store them in full and on time. It gives the tax authorities various taxation powers, including checking taxpayers' books and other tax-related information and verifying taxpayers' taxable consumer goods. It can be seen that the tax collection and management activities of the tax authorities have produced certain monitoring and deterrent effects on tax avoidance by enterprises. In general, the aggressiveness of a company's tax avoidance depends on the balance between costs and benefits. The benefits are mainly reflected in the increase in cash flow. The costs are mainly reflected in the amount of punishment and reputation loss faced by the tax collection agency after investigation by the tax collection authorities. It can be seen that the level of tax collection and management also determines the transaction cost of tax avoidance. The increase in tax collection and administration strength means that the tax authority's tolerance for corporate tax avoidance activities will be reduced, the probability of tax avoidance activities being investigated and the company's tax avoidance costs will increase significantly, and companies will thus reduce their participation in tax avoidance activities. In addition, the increase in the tax collection and management of tax authorities also increases the difficulty for enterprises to avoid taxation and plugs the loopholes in the collection and management. Therefore, in areas where tax collection and management are strong, the incentive for companies to avoid tax may be weaker due to transaction cost considerations. Under such conditions, as discussed in Hypothesis 1, enterprises that are supported by industrial policies will have their financing constraints eased, and subjective intentions will weaken and external conditions will improve, so companies will avoid tax avoidance.

H3: Under the same conditions, the impact of industrial policies on the level of corporate tax avoidance is even more pronounced in regions with low tax collection and management.

\section{Research Design}

\subsection{Research Samples and Data Sources}

This paper selects companies listed in the A-share market in Shanghai and 
Shenzhen during 2001 to 2015 to study the impact of industrial policies on corporate tax avoidance. The financial data used in this paper comes from CSMAR's Taian database, and some of the data is selected from the Wind database. In addition, part of the industrial policy data refers to Chen Donghua's (2010) [4] article, and the other part is collected from the policies and regulations publicized by the National Development and Reform Commission of China. We filter out the appropriate sample data according to the following criteria:

1) Excluding sample data with asset-liability ratio greater than 1, that is, ownership equity being negative; 2) excluding financial industry data; 3 ) excluding samples with missing main variables; 4) excluding samples which have been ST, PT over the years. At the same time, in order to ensure the robustness of the research results, this paper processed the continuous data at the $1 \%$ level. Finally, we obtained 2566 companies and 23,027 observations. The data collation and analysis of this paper were performed under Microsoft Excel 2013 and STATA 12.0 .

\subsection{Variable Design}

\subsubsection{Explained Variables}

Corporate tax avoidance: This article uses the indicator of accounting-tax discrepancies (BTD) to measure the level of corporate income tax avoidance. Specifically, the expression formula of the indicator can be expressed as: BTD = (Accounting profit before tax - Taxable income)/Total assets at the end of the period. Taxable income amount $=$ income tax expense/nominal income tax rate. The larger the BTD, the greater the difference between the accounting profit and the taxable income, the higher the tax avoidance of the company, so the more the company has the incentive to avoid tax. In addition, this article also refers to the practice of Desai and Dharmapala (2005) [14] and selects the accounting-tax discrepancies (DDBTD) after removing the factors that affect the accrual accounting profit to measure the tax avoidance level of the company. Specifically, DDBTD can be calculated from the following company fixed effect model:

$$
B T D_{i, t}=\beta T A C C_{i, t}+\mu_{i, t}+\varepsilon_{i, t}
$$

TACC $=($ net profit - net cash flow from operating activities $) /$ total assets at the end of the period; $\varepsilon_{i}$ represents the average value of company $i$ residuals in the sample period; $\varepsilon_{i, t}$ represents the degree of deviation of the th year residual from $\mu_{i}$; DDBTD equals to the sum of the two; it represents the portion of the BTD that cannot be explained by accrued profits.

\subsubsection{Explaining Variables}

Industrial Policy: Refer to Chen Donghua et al. (2010) [4] for measuring industrial policies. This paper uses the following measurements:

First of all, in accordance with the various industrial policy documents issued by the National Development and Reform Commission, the following screening criteria are made: 1) Industry-policy-supported recognition standards for an in- 
dustry are the key words in the industry policy document: "Strived Development," "Encouraging Development," "Active Development," and "Adjustment"; 2) The implementation time is the time specified in the industrial policy document; 3) If the period for the implementation of the policy is not stated in the industrial policy document, this document shall be deemed as 5 years. 4) For the detailed consideration of the industrial division supported by industrial policy, the three-digit code of the industry code is used in this article.

Finally, a dumb variable IP is set for the industrial policy. If the industry year in which the company is located is within the period supported by the industrial policy promulgated by the China Development and Reform Commission, the dummy variable takes a value of 1 , otherwise it is 0 .

\subsubsection{Control Variables}

1) Company size (SIZE)

Under normal circumstances, the larger the company's size is, the easier it is for the public to understand. And it also has a better information disclosure system, and the information asymmetry with external investors is low, so there is less room for tax avoidance activities and tax avoidance. Lower.

2) Growth of the company (MTB)

According to the company's life cycle theory, the environment in which companies are located varies greatly in different periods. The rapid growth of companies in the high-growth stage is faced with higher financing constraints and the incentive for tax avoidance is even stronger.

3) Assets and Liabilities (LEV)

Defond (1994), based on the research results of the enterprise earnings management model, believe that in order to reduce the losses caused by violating the debt contract, the company may adopt the surplus management mode of increasing accounting profits. Therefore, this article also controls this variable as one of the factors affecting the size of the company's tax avoidance. We use total liabilities/total assets to describe its size.

In addition, this article refers to the research of Cai Hongbiao and Rao Pingui (2015) [26] and regards the return on total assets, the proportion of fixed assets, the proportion of intangible assets, and the loss in the previous year as the control variables in the regression.

\subsubsection{Grouping Variables}

1) Property property grouping variable (SOE)

Based on the nature of the ultimate controller, this paper determines the nature of the company's property rights. The SOE is a dummy variable. When the final control of the company is a state-owned unit, it takes 1 ; otherwise it is 0 .

2) Tax collection intensity (DTE)

TE is used as a tax collection and management index for group control in this paper. This article refers to the practices of Ye Kangtao and Liu Xing (2011) [27] and uses the ratio of actual tax revenues in each region and expected tax reve- 
nues to measure the tax collection and management intensity of tax authorities in a certain region. To calculate the DTE, first we use the models of Mertens (2003) [28] and $\mathrm{Xu}$ et al. (2010) [29] to estimate the expected tax revenue for each region:

$$
\frac{T_{i, t}}{G D P_{i, t}}=\alpha_{0}+\alpha_{1} \times \frac{I N D 1_{i, t}}{G D P_{i, t}}+\alpha_{2} \times \frac{I N D 2_{i, t}}{G D P_{i, t}}+\alpha_{3} \times \frac{O P E N N E S S_{i, t}}{G D P_{i, t}}+\varepsilon_{i t}
$$

$\frac{T_{i, t}}{G D P_{i, t}}$ represents the local tax revenue at the end of the year divided by the GDP of the year in each region; IND1 represents the value of the primary industry at the end of each year in each region. IND2 represents the secondary industry output value of each region at the end of the year; OPENNESS represents the degree of openness of a region, which is expressed as the total amount of imports and exports at the end of each year in each region. Substitute the above data from each region into the above model for OLS regression, and then calculate the expected $\frac{T_{i, t}}{G D P_{i, t}}$. We express it as $\frac{T_{i, t}}{G D P_{i, t_{\text {_est }}}}$. The tax collection strength, TE, is equal to the ratio of the actual tax in the region to the estimated tax:

$$
T E_{i, t}=\left(\frac{T_{i, t}}{G D P_{i, t}}\right) / \frac{T_{i, t}}{G D P_{i, t_{-} e s t}}
$$

The larger the value of this variable is, the greater the tax collection and administration of tax authorities in the area where the company is located are. After estimating the TE, we grouped the samples according to the median criteria, constructed a dummy variable DTE, and assigned a value of 1 when the TE was greater than the sample median, and 0 otherwise.

\subsection{Model Building}

To explore the hypothesis 1, we establish the following model:

TAX AVOIDANCE $(\mathrm{BTD}, \mathrm{DDBTD})=\alpha_{0}+\alpha_{1} \mathrm{IP}_{i, t}+\alpha_{2} \mathrm{SIZE}+\alpha_{3} \mathrm{MTD}$

$$
\begin{aligned}
& +\alpha_{4} \mathrm{LEV}+\alpha_{5} \mathrm{ROA}+\alpha_{6} \mathrm{PPE}+\alpha_{7} \mathrm{INTANG} \\
& +\alpha_{8} \mathrm{LOSS}+\alpha_{9} \mathrm{YEAR}+\alpha_{10} \mathrm{INDUSTRY}+\varepsilon
\end{aligned}
$$

TAX AVOIDANCE (BTD, DDBTD) is a tax avoidance index (BTD and DDBTD); IP is a dummy variable for industrial policy incentives; in all OLS regressions, the industries and years in which the company was located were controlled.

To test Hypothesis 2, the model (1) is grouped and regressed according to the nature of property rights. If there are differences in the significance and coefficients of the regression results between the state-owned and non-state-owned groups, it is indicated that Hypothesis 2 is supported by empirical evidence. To test hypothesis 3, the samples were grouped and regressed according to the strength of tax collection. If the significance and coefficient of the regression re- 
sults in the high tax collection strength group and the low tax collection strength group are different, it indicates that hypothesis 3 is supported by empirical evidence. For the definition of each variable, see Table 1.

\section{Regression Results and Empirical Analysis}

This chapter will empirically analyze the relationship between industrial policies and corporate tax avoidance. First of all, we use measurement tools to perform full sample OLS regression analysis from an overall analysis of industrial policy on the corporate tax avoidance. Then according to the two criteria of the nature of property rights and the strength of tax collection and management, the samples were grouped and tested to see whether the impact of industrial policies on corporate tax avoidance was different under different property rights and the strength of tax collection and management.

\subsection{Correlation Analysis and Descriptive Statistics}

Table 2 shows the correlation analysis results of the main variables. It can be seen from the table results that the relevance of the main variables is within a reasonable range, and it can be considered that there is no serious multicollinearity among the variables. From the table, it can be seen that both BTD and DDBTD are positively correlated with IP, and the correlation coefficients are 0.0092 and 0.0073 . This is contrary to hypothesis 1 . In order to control the influence of other variables, we need to do further regression analysis.

Table 1. Definition of major variables.

\begin{tabular}{|c|c|c|}
\hline Variable type & Variable symbol & Definition \\
\hline Explained variable & TAX AVOIDANCE & Tax Avoidance Indicators: BTD, DDBTD \\
\hline \multirow[t]{2}{*}{ Explanatory variable } & IP & $\begin{array}{l}\text { When the company's industry year is within the period } \\
\text { of industrial policy support, IP is } 1 \text {, otherwise it is } 0 \text {. }\end{array}$ \\
\hline & SOE & $\begin{array}{l}\text { Nature of property. State-owned enterprise is assigned } \\
\text { to } 1 \text {, otherwise it is } 0\end{array}$ \\
\hline \multirow[t]{4}{*}{ Grouping variable } & DTE & $\begin{array}{l}\text { The ratio of actual tax revenue to expected tax revenue } \\
\text { in each region is taken as an alternative variable to the } \\
\text { tax administration strength of tax authorities in the } \\
\text { region. The greater the value, the greater the strength } \\
\text { of tax collection. DTE is } 1 \text { when TE is greater than the } \\
\text { median of the sample, } 0 \text { otherwise }\end{array}$ \\
\hline & SIZE & Enterprise size, natural logarithm of total assets \\
\hline & MTB & $\begin{array}{l}\text { Growth indicator, market value of company's equity } \\
\text { divided by book value }\end{array}$ \\
\hline & LEV & Assets and liabilities \\
\hline \multirow[t]{4}{*}{ Control variable } & $\mathrm{ROA}$ & Return on Assets \\
\hline & PPE & The proportion of fixed assets \\
\hline & INTANG & Proportion of intangible assets \\
\hline & LOSS & $\begin{array}{l}\text { Whether the loss was in the previous year, the loss was } \\
\text { taken as } 1 \text {, otherwise it was } 0\end{array}$ \\
\hline
\end{tabular}


Table 2. Correlation Analysis.

\begin{tabular}{|c|c|c|c|c|c|c|c|c|c|c|}
\hline & BTD & DDBTD & IP & SIZE & MTB & LEV & ROA & PPE & INTANG & LOSS \\
\hline BTD & \multicolumn{4}{|c|}{1.0000} & & & & & & \\
\hline DDBTD & $0.2623^{*}$ & \multicolumn{2}{|c|}{1.0000} & & & & & & & \\
\hline IP & 0.0092 & 0.0073 & \multicolumn{2}{|c|}{1.0000} & & & & & & \\
\hline SIZE & $0.0629^{\star}$ & $0.0473^{\star}$ & $-0.0657^{\star}$ & \multicolumn{2}{|c|}{1.0000} & & & & & \\
\hline MTB & $-0.0766^{\star}$ & $-0.0541^{\star}$ & 0.0091 & $-0.3318^{\star}$ & \multicolumn{2}{|c|}{1.0000} & & & & \\
\hline LEV & $-0.1958^{\star}$ & $0.0181^{\star}$ & $-0.1155^{*}$ & $0.3641^{*}$ & $0.0868^{*}$ & \multicolumn{2}{|c|}{1.0000} & & & \\
\hline $\mathrm{ROA}$ & $0.6582^{\star}$ & $0.0205^{\star}$ & $0.0332^{\star}$ & $0.0782^{\star}$ & -0.0030 & $-0.3565^{\star}$ & \multicolumn{2}{|c|}{1.0000} & & \\
\hline PPE & $-0.0371^{\star}$ & $0.3280^{*}$ & $0.0684^{*}$ & $0.0775^{*}$ & $-0.1240^{*}$ & $0.0797^{\star}$ & $-0.1117^{*}$ & \multicolumn{2}{|c|}{1.0000} & \\
\hline INTANG & $-0.0411^{\star}$ & $0.0685^{\star}$ & 0.0082 & $-0.0275^{\star}$ & $0.0612^{\star}$ & -0.0145 & $-0.0400^{*}$ & 0.0108 & \multicolumn{2}{|c|}{1.0000} \\
\hline LOSS & $-0.1375^{\star}$ & $0.0318^{\star}$ & -0.0043 & $-0.0987^{\star}$ & $0.1704^{*}$ & $0.1724^{*}$ & $-0.2285^{\star}$ & $0.0701^{\star}$ & $0.0489^{*}$ & 1.0000 \\
\hline
\end{tabular}

Descriptive statistics of corporate tax avoidance indicators and related influencing factors are shown in Table 3. The average value of industrial policy variables is 0.645 , which indicates that $64.5 \%$ of all listed companies were supported by industrial policies during the sample period. This shows that during the three five-year planning period, industrial policies have a wide range of regulation. This paper uses two different calculation methods to derive the corporate tax avoidance indicators, namely BTD and DDBTD. It can be seen that the mean and median of BTD are $-0.4 \%$ and $-0.1 \%$, respectively, and the DDBTD after the impact of accruals is excluded. The mean and median are $0.6 \%$ and $0.9 \%$, respectively, indicating that accruals have a greater impact on the calculation of tax avoidance indicators. The ROA mean (median) of the profitability index was $3.8 \%(3.5 \%)$, the minimum was $-31.1 \%$, and the maximum was $23 \%$, indicating that the profitability of each company was quite different. The mean growth index MTB is 3.889, indicating that the overall growth of listed companies in China is faster. The average PPE is $25.9 \%$, which means that on average, $25.9 \%$ of the total assets of the sample companies are fixed assets. The INTANG average of intangible assets is only $4.5 \%$, which means that on average, $4.5 \%$ of the total assets in the sample companies are intangible assets, and the proportion is generally low. The average value of the group variable SOE is $53.8 \%$, indicating that $46.2 \%$ of the sample companies are private enterprises. The mean value of DTE is $42.7 \%$, indicating that $42.7 \%$ of the sample companies are located in areas with high tax administration strength.

\subsection{Regression Analysis}

\subsubsection{Full Sample Regression}

To further examine the impact of industrial policy on corporate tax avoidance, this paper establishes a regression model for empirical analysis. Table 4 is the full sample OLS regression result of industrial policy on corporate tax avoidance. It can be seen that the coefficient of the industrial policy dummy variable IP is 
Table 3. Descriptive statistics of major variables.

\begin{tabular}{ccccccccc}
\hline Variable & Mean & $25 \%$ & Median & $75 \%$ & Min & Max & Sd & Obs \\
\hline BTD & -0.004 & -0.016 & -0.001 & 0.013 & -0.278 & 0.154 & 0.050 & 23027 \\
DDBTD & 0.006 & -0.033 & 0.009 & 0.051 & -0.269 & 0.225 & 0.078 & 23027 \\
IP & 0.645 & 0.000 & 1.000 & 1.000 & 0.000 & 1.000 & 0.479 & 23027 \\
SIZE & 21.700 & 20.843 & 21.536 & 22.344 & 18.856 & 26.330 & 1.229 & 23027 \\
MTB & 3.889 & 1.778 & 2.766 & 4.509 & 0.222 & 27.606 & 3.834 & 23027 \\
LEV & 0.460 & 0.303 & 0.467 & 0.618 & 0.048 & 0.937 & 0.207 & 23027 \\
ROA & 0.038 & 0.012 & 0.035 & 0.065 & -0.311 & 0.230 & 0.061 & 23027 \\
PPE & 0.259 & 0.119 & 0.227 & 0.372 & 0.002 & 0.757 & 0.179 & 23027 \\
INTANG & 0.045 & 0.011 & 0.029 & 0.056 & -0.027 & 0.895 & 0.064 & 23027 \\
SOE & 0.538 & 0.000 & 1.000 & 1.000 & 0.000 & 1.000 & 0.499 & 23027 \\
\hline
\end{tabular}

Table 4. OLS regression results of industrial policy and corporate tax avoidance.

\begin{tabular}{|c|c|c|}
\hline & BTD & DDBTD \\
\hline \multirow[t]{2}{*}{ IP } & $-0.002^{\star * *}$ & $-0.002^{*}$ \\
\hline & $(-3.43)$ & $(-1.87)$ \\
\hline \multirow[t]{2}{*}{ SIZE } & $-0.003^{\star \star \star}$ & $0.002^{\star * *}$ \\
\hline & $(-12.61)$ & $(4.09)$ \\
\hline \multirow[t]{2}{*}{ MTB } & $-0.002^{\star * *}$ & $-0.001^{* * *}$ \\
\hline & $(-16.64)$ & $(-3.72)$ \\
\hline \multirow[t]{2}{*}{ LEV } & $0.026^{* * *}$ & 0.005 \\
\hline & $(16.14)$ & $(1.64)$ \\
\hline \multirow[t]{2}{*}{ ROA } & $0.576^{* * *}$ & $0.084^{* * *}$ \\
\hline & (73.19) & (7.18) \\
\hline \multirow[t]{2}{*}{ PPE } & $0.010^{* * *}$ & $0.129^{* \star *}$ \\
\hline & $(7.18)$ & $(41.92)$ \\
\hline \multirow[t]{2}{*}{ INTANG } & -0.001 & $0.088^{* * *}$ \\
\hline & $(-0.16)$ & $(12.36)$ \\
\hline \multirow[t]{2}{*}{ LOSS } & $0.004^{* * *}$ & $0.007^{\star * *}$ \\
\hline & $(3.58)$ & $(3.22)$ \\
\hline \multirow[t]{2}{*}{ Constant } & $0.060^{* * *}$ & $-0.063^{* * *}$ \\
\hline & $(9.97)$ & $(-5.01)$ \\
\hline Industry & Control & Control \\
\hline Year & Control & Control \\
\hline Obs & 23027 & 23027 \\
\hline Adj. $R^{2}$ & 0.558 & 0.164 \\
\hline
\end{tabular}

significantly negative (the former is significant at the $1 \%$ level and the latter is significant at the $10 \%$ level), both in the regression results of the BTD or DDBTDD as the explanatory variables. That is to say, compared with companies that are not supported by industrial policies, enterprises that are supported by 
industrial policies have lower tax avoidance, which confirms this hypothesis. From the perspective of control variables, variables such as profitability, asset-liability ratio, and loss in the previous year all have positive effects on tax avoidance, and growth has a negative correlation with tax avoidance.

\subsubsection{Group Regression by Nature of Property}

Table 5 reports the results of the regression of industrial policies and tax avoidance under the nature of property rights grouping. In the regression results with BTD as the explanatory variable, the coefficient of IP in the non-SOE group was significantly negative at the $10 \%$ significance level, and the coefficient of IP in the SOE group was significantly negative at the $1 \%$ significance level. The correlation test $(P$ value $=0.6422)$ cannot reject the null hypothesis that both coefficients are equal. That is to say, both state-owned and non-state-owned enterprises, the degree of tax avoidance (measured by BTD) of enterprises supported by industrial policies are not supported by industrial policies. The low level of the firm is contrary to the hypothesis 2 proposed in this paper. From the result of the regression of the DDBTD as an explanatory variable, the IP coefficient is significantly negative at the $5 \%$ significance level in the non-SOE group. The

Table 5. OLS regression results of industry policy and corporate tax avoidance level.

\begin{tabular}{|c|c|c|c|c|}
\hline & BTD & BTD & DDBTD & DDBTD \\
\hline & Non-SOE & SOE & Non-SOE & SOE \\
\hline \multirow[t]{2}{*}{ IP } & $-0.002^{*}$ & $-0.002^{\star \star \star}$ & $-0.005^{\star *}$ & -0.000 \\
\hline & $(-1.69)$ & $(-2.69)$ & $(-2.41)$ & $(-0.24)$ \\
\hline \multirow[t]{2}{*}{ SIZE } & $-0.004^{* * *}$ & $-0.004^{* * *}$ & $0.002^{* *}$ & $0.002^{\star *}$ \\
\hline & $(-7.46)$ & $(-11.36)$ & $(2.29)$ & $(2.37)$ \\
\hline \multirow[t]{2}{*}{ MTB } & $-0.002^{\star * *}$ & $-0.002^{* * *}$ & -0.000 & $-0.001^{\star * *}$ \\
\hline & $(-9.14)$ & $(-15.07)$ & $(-1.52)$ & $(-3.00)$ \\
\hline \multirow[t]{2}{*}{ LEV } & $0.023^{* * *}$ & $0.026^{* * *}$ & 0.000 & 0.003 \\
\hline & $(9.53)$ & (11.60) & $(0.05)$ & $(0.74)$ \\
\hline \multirow[t]{2}{*}{ ROA } & $0.558^{\star * *}$ & $0.599^{* * *}$ & $0.049^{* * *}$ & $0.122^{* * *}$ \\
\hline & $(47.66)$ & (55.02) & $(2.76)$ & $(7.76)$ \\
\hline \multirow[t]{2}{*}{ PPE } & $0.015^{\star * *}$ & $0.008^{\star * *}$ & $0.146^{* * *}$ & $0.120^{\star * *}$ \\
\hline & $(5.74)$ & $(4.69)$ & $(25.67)$ & (31.88) \\
\hline \multirow[t]{2}{*}{ INTANG } & -0.002 & -0.002 & $0.067^{\star * *}$ & $0.095^{\star * *}$ \\
\hline & $(-0.33)$ & $(-0.61)$ & $(4.81)$ & (11.79) \\
\hline \multirow[t]{2}{*}{ LOSS } & $0.004^{* *}$ & $0.003^{* * *}$ & 0.004 & $0.009^{* * *}$ \\
\hline & $(2.42)$ & $(2.77)$ & $(1.25)$ & $(3.64)$ \\
\hline \multirow[t]{2}{*}{ Constant } & $0.065^{\star * *}$ & $0.069^{* * *}$ & $-0.069^{* * *}$ & $-0.045^{* * *}$ \\
\hline & $(6.15)$ & $(9.05)$ & $(-2.87)$ & $(-2.91)$ \\
\hline Industry & Control & Control & Control & Control \\
\hline Year & Control & Control & Control & Control \\
\hline Obs & 10627 & 12400 & 10627 & 12400 \\
\hline Adj. $R^{2}$ & 0.569 & 0.555 & 0.140 & 0.169 \\
\hline
\end{tabular}


coefficient is not significant, which supports the hypothesis 3 to a certain extent. Compared with non-state-owned enterprises, state-owned enterprises are less affected by industrial policies. Non-state-owned enterprises are more likely to be affected by industrial policies than their state-owned counterparts (as measured by DDBTD). In other words, non-state-owned enterprises supported by industrial policies have lower tax avoidance (measured by DDBTD) than non-state-owned enterprises that are not supported by industrial policies; while in state-owned enterprises, state-owned enterprises supported by industrial policies have not received industrial policies. The level of tax avoidance (measured by DDBTD) of supported state-owned enterprises is not significantly different.

\subsubsection{Regression by Tax Collection Intensity}

Table 6 reports the regression results of industrial policies and corporate tax avoidance under the tax administration strength group. It can be seen from the table that in the regression with BTD as the explanatory variable, the coefficient of IP in the low tax collection strength group is significantly negative at the $5 \%$ significance level; in the regression with DDBTD as the explanatory variable, low taxation. The coefficient of IP in the collection strength group was significantly

Table 6. OLS regression results of industrial policy and corporate tax avoidance under the strength of tax collection and management.

\begin{tabular}{|c|c|c|c|c|}
\hline & BTD & BTD & DDBTD & DDBTD \\
\hline & Low & High & Low & High \\
\hline \multirow[t]{2}{*}{ IP } & $-0.002^{* * *}$ & -0.001 & $-0.003^{*}$ & -0.001 \\
\hline & $(-3.05)$ & $(-1.52)$ & $(-1.95)$ & $(-0.65)$ \\
\hline \multirow[t]{2}{*}{ SIZE } & $-0.004^{\star * *}$ & $-0.003^{\star * *}$ & 0.001 & $0.004^{\star * *}$ \\
\hline & $(-10.16)$ & $(-7.96)$ & $(1.20)$ & $(4.78)$ \\
\hline \multirow[t]{2}{*}{ MTB } & $-0.002^{* * *}$ & $-0.002^{* * *}$ & $-0.001^{\star * *}$ & $-0.001^{* * *}$ \\
\hline & $(-12.64)$ & $(-11.29)$ & $(-2.72)$ & $(-2.67)$ \\
\hline \multirow[t]{2}{*}{ LEV } & $0.027^{* * *}$ & $0.025^{\star * *}$ & $0.008^{*}$ & 0.003 \\
\hline & (12.83) & (10.25) & $(1.71)$ & $(0.67)$ \\
\hline \multirow[t]{2}{*}{ ROA } & $0.577^{\star * *}$ & $0.577^{* * *}$ & $0.081^{* * *}$ & $0.089^{* * *}$ \\
\hline & $(57.01)$ & (46.73) & $(5.18)$ & $(5.01)$ \\
\hline \multirow[t]{2}{*}{ PPE } & $0.005^{\star * *}$ & $0.016^{* * *}$ & $0.134^{* * *}$ & $0.122^{* * *}$ \\
\hline & (2.79) & $(7.44)$ & $(32.20)$ & (26.24) \\
\hline \multirow[t]{2}{*}{ INTANG } & -0.002 & -0.001 & $0.086^{\star * *}$ & $0.094^{\star * *}$ \\
\hline & $(-0.42)$ & $(-0.25)$ & $(9.36)$ & $(8.27)$ \\
\hline \multirow[t]{2}{*}{ LOSS } & $0.005^{* * *}$ & 0.001 & $0.009^{* * *}$ & 0.004 \\
\hline & $(4.33)$ & $(0.81)$ & $(3.22)$ & $(1.33)$ \\
\hline \multirow[t]{2}{*}{ Constant } & $0.072^{\star * *}$ & $0.051^{* * *}$ & $-0.032^{*}$ & $-0.095^{\star * *}$ \\
\hline & $(8.55)$ & $(5.96)$ & $(-1.82)$ & $(-5.29)$ \\
\hline Industry & Control & Control & Control & Control \\
\hline Year & Control & Control & Control & Control \\
\hline Obs & 13197 & 9830 & 13197 & 9830 \\
\hline Adj. $\mathrm{R}^{2}$ & 0.571 & 0.546 & 0.168 & 0.162 \\
\hline
\end{tabular}


negative at the level of $10 \%$ significance, while the coefficient of IP in the high tax collection intensity group was not significant. That is, in areas with low tax revenue collection, enterprises that are supported by industrial policies have lower tax avoidance levels than those that are not supported by industrial policies. In areas with high tax revenue collection, enterprises that are supported by industrial policies have not received any industry support. There is no significant difference in the degree of tax avoidance among enterprises supported by policies. It is consistent with the hypothesis 3 of this article.

\subsection{Robust Test}

\subsubsection{Replacement of Explanatory Variables}

Based on the variable IP, this section also separates key industries according to keywords, and sets a new virtual variable IP1. When the five-year plan clearly states that the industry is focused on development or support, it takes 1; otherwise it is 0 . We construct the following model for regression analysis:

TAX AVOIDANCE (BTD,DDBTD $)=\alpha_{0}+\alpha_{1} \mathrm{IP} 1_{i, t}+\alpha_{2} \mathrm{SIZE}+\alpha_{3} \mathrm{MTD}$

$$
\begin{aligned}
& +\alpha_{4} \mathrm{LEV}+\alpha_{5} \mathrm{ROA}+\alpha_{6} \mathrm{PPE}+\alpha_{7} \mathrm{INTANG} \\
& +\alpha_{8} \mathrm{LOSS}+\alpha_{9} \mathrm{YEAR}+\alpha_{10} \mathrm{INDUSTRY}+\varepsilon
\end{aligned}
$$

The regression results are shown in Table 7. From the table, it can be seen

Table 7. Robust test (1).

\begin{tabular}{ccc}
\hline & BTD & DDBTD \\
\hline IP1 & $-0.002^{* *}$ & 0.000 \\
& $(-2.48)$ & $(0.25)$ \\
SIZE & $-0.003^{* * *}$ & $0.002^{* * *}$ \\
& $(-12.53)$ & $(4.17)$ \\
MTB & $-0.002^{* * *}$ & $-0.001^{* * *}$ \\
& $(-16.67)$ & $(-3.78)$ \\
LEV & $0.026^{* * *}$ & $0.006^{*}$ \\
& $(16.17)$ & $(1.71)$ \\
ROA & $0.576^{* * *}$ & $0.084^{* * *}$ \\
& $(73.16)$ & $(7.16)$ \\
PPE & $0.010^{* * *}$ & $0.129^{* * *}$ \\
& $(7.21)$ & $(41.93)$ \\
INTANG & -0.001 & $0.088^{* * *}$ \\
& $(-0.28)$ & $(12.31)$ \\
LOSS & $0.004^{* * *}$ & $0.007^{* * *}$ \\
& $(3.58)$ & $(3.21)$ \\
Constant & $0.058^{* * *}$ & $-0.066^{* * *}$ \\
& $(9.82)$ & $(-5.36)$ \\
Industry & Control & Control \\
Year & Control & Control \\
Obs & 23027 & 23027 \\
Adj. $R^{2}$ & 0.558 & 0.164 \\
& & \\
& &
\end{tabular}


that in the regression results of BTD as an explanatory variable, the coefficients of IP1, the industrial policy dummy variable, are all significantly negative at the $5 \%$ significance level, compared with the previous part. The results are consistent, although this result is not significant in the regression results of DDBTD as an interpreted variable.

\subsubsection{Replace Explained Variables}

This article refers to the methods of Liu Xing and Ye Kangtao (2013) and uses "RATE = nominal income tax rate - actual income tax rate" to measure the tax avoidance level of a company. The larger the value of this variable is, the higher the company's tax avoidance is. Then we build the following model for OLS regression analysis:

$$
\begin{aligned}
& \text { TAX AVOIDANCE(BTD,DDBTD })=\alpha_{0}+\alpha_{1} \mathrm{IP}_{i, t}+\alpha_{2} \mathrm{SIZE}+\alpha_{3} \mathrm{MTD} \\
& +\alpha_{4} \mathrm{LEV}+\alpha_{5} \mathrm{ROA}+\alpha_{6} \mathrm{PPE}+\alpha_{7} \mathrm{INTANG} \\
& +\alpha_{8} \mathrm{LOSS}+\alpha_{9} \mathrm{YEAR}+\alpha_{10} \mathrm{INDUSTRY}+\varepsilon
\end{aligned}
$$

The results of the regression are shown in Table 8. From the table, we can see

\begin{tabular}{|c|c|}
\hline & RATE \\
\hline \multirow[t]{2}{*}{ IP } & $-0.010^{\star * *}$ \\
\hline & $(-3.76)$ \\
\hline \multirow[t]{2}{*}{ SIZE } & -0.001 \\
\hline & $(-0.50)$ \\
\hline \multirow[t]{2}{*}{ MTB } & $0.001^{\star *}$ \\
\hline & $(2.13)$ \\
\hline \multirow[t]{2}{*}{ LEV } & $-0.016^{\star *}$ \\
\hline & $(-2.31)$ \\
\hline \multirow[t]{2}{*}{$\mathrm{ROA}$} & $0.740^{* * *}$ \\
\hline & $(25.71)$ \\
\hline \multirow[t]{2}{*}{ PPE } & $0.045^{\star * *}$ \\
\hline & $(6.68)$ \\
\hline \multirow[t]{2}{*}{ INTANG } & 0.018 \\
\hline & $(1.10)$ \\
\hline \multirow[t]{2}{*}{ LOSS } & 0.009 \\
\hline & $(1.53)$ \\
\hline Industry & Control \\
\hline Year & Control \\
\hline \multirow[t]{2}{*}{ Constant } & $0.065^{\star \star}$ \\
\hline & $(2.57)$ \\
\hline Obs & 20739 \\
\hline Adj. $R^{2}$ & 0.073 \\
\hline
\end{tabular}
that the IP coefficient of the industrial policy dummy variable is significantly

Table 8. Robust test (2). 
negative at the $1 \%$ significance level, which means that compared to enterprises that are not supported by industrial policies, enterprises that are supported by industrial policies have lower tax avoidance. This further confirms the assumption 1 of this paper.

\subsubsection{Select Specific Samples}

From the total sample, enterprises that were received industrial policy support during the "Eleventh Five-Year Plan" period but are supported by industrial policies during the "Twelfth Five-Year Plan" period are taken as research samples and are returned according to Model (1).

The regression results are shown in Table 9. From the table, it can be seen that in the regression results of BTD as an explanatory variable, the coefficient of the industrial policy dummy variable is significantly negative at the $10 \%$ significance level; in the regression results of the explanatory variables, the coefficient of the industrial policy dummy variable IP is significantly negative at the level of $5 \%$ significance. That is, the degree of tax avoidance of enterprises after industrial policy support is lower than that of when the industrial policy is not adopted. This is basically consistent with the assumption of Hypothesis 1 .

Table 9. Robust test (3).

\begin{tabular}{|c|c|c|}
\hline & BTD & DDBTD \\
\hline \multirow[t]{2}{*}{ IP } & $-0.003^{*}$ & $-0.004^{\star *}$ \\
\hline & $(-1.90)$ & $(-2.16)$ \\
\hline \multirow[t]{2}{*}{ SIZE } & -0.000 & -0.000 \\
\hline & $(-0.62)$ & $(-0.48)$ \\
\hline \multirow[t]{2}{*}{ МTB } & $0.011^{\star * *}$ & $0.012^{* * *}$ \\
\hline & $(8.72)$ & $(8.94)$ \\
\hline \multirow[t]{2}{*}{ LEV } & $0.007^{\star}$ & 0.006 \\
\hline & $(1.69)$ & $(1.38)$ \\
\hline \multirow[t]{2}{*}{ ROA } & $0.581^{\star * *}$ & $0.552^{\star * *}$ \\
\hline & (32.39) & (28.90) \\
\hline \multirow[t]{2}{*}{ PPE } & $0.013^{* * *}$ & $0.019^{* * *}$ \\
\hline & $(2.97)$ & $(4.56)$ \\
\hline \multirow[t]{2}{*}{ INTANG } & -0.011 & -0.003 \\
\hline & $(-1.07)$ & $(-0.30)$ \\
\hline \multirow[t]{2}{*}{ LOSS } & $0.006^{* *}$ & $0.005^{\star}$ \\
\hline & $(2.10)$ & $(1.67)$ \\
\hline Industry & Control & Control \\
\hline Year & Control & Control \\
\hline \multirow[t]{2}{*}{ Constant } & $-0.026^{*}$ & $-0.028^{*}$ \\
\hline & $(-1.81)$ & $(-1.96)$ \\
\hline Obs & 5220 & 5220 \\
\hline Adj. $R^{2}$ & 0.484 & 0.465 \\
\hline
\end{tabular}




\section{Research Conclusions}

\subsection{Conclusions}

This article discusses the relationship between industrial policy and corporate tax avoidance behavior from the perspective of financing constraints, the nature of property rights, and the strength of tax collection and management. After a series of empirical analysis, the following conclusions are drawn:

Conclusion 1): Industrial policies have a certain influence on the tax avoidance of enterprises. After controlling many factors that may affect the tax avoidance of enterprises, overall, under the same conditions, enterprises under the support of industrial policies have lower tax avoidance than those without industrial policy support. From the perspective of financing constraints, in order to achieve the development goals in the "Five-Year Plan", the government will generally relax the qualifications for bank credit approval, stock market listing, and refinancing for supporting industry companies, and direct a large amount of resources to the supported industries so as to ease the financing constraints of the company. The ease of corporate financing constraints has increased the unit cost of tax avoidance. Because at this time, the difficulty of obtaining financing from outside the company becomes smaller, and the cost becomes lower. With the increase of unit cost and unit revenue, the tax avoidance of enterprises has been reduced.

Conclusion 2): The effect of the nature of property rights on the relationship between industrial policies and corporate tax avoidance results is uncertain. Whether it is state-owned enterprises or non-state-owned enterprises, the level of tax avoidance (measured by BTD) of enterprises supported by industrial policies is lower than that of enterprises that are not supported by industrial policies. The results in another group of results show that non-state-funded enterprises are not supported by industrial policies. The level of tax avoidance (measured by DDBTD) of state-owned enterprises is lower than that of non-state-owned enterprises that are not supported by industrial policies; while in state-owned enterprises, state-owned enterprises supported by industrial policies and state-owned enterprises that are not supported by industrial policies have their tax avoidance (DDBTD) measured no significant difference.

Conclusion 3): The strength of regional tax collection has a certain influence on the relationship between industrial policy and corporate tax avoidance. The empirical results show that in regions with low tax revenue collection, enterprises that are supported by industrial policies have lower tax avoidance levels than those that are not supported by industrial policies, while those that are supported by industrial policies do not. There is no significant difference in the degree of tax avoidance for enterprises supported by industrial policies.

\subsection{Implications}

1) In the current era of widespread tax avoidance in China, optimizing and adjusting industrial policies and strengthening implementation can alleviate the 
financing constraints of specific enterprises, thereby reducing the tax avoidance activities of these enterprises.

2) The tax supervision department may pay more attention to tax avoidance by enterprises that are not supported by industrial policies based on whether the company is supported by industrial policies; strengthen tax inspections; establish and improve the organizational structure of tax auditing; implement key auditing systems; strengthen the legitimacy and law enforcement of tax auditors' law enforcement; and implement reasonable, legal and high-quality supervision and inspection of taxpayers' duty-to-performance status.

3) Accelerate tax legislation and supervision in areas with weak tax collection and management, and constantly improve tax-related legal systems and their implementation procedures. Tax authorities need to strengthen tax collection and management in accordance with the law, constantly optimize and improve the collection and management services so as to increase the tax collection rate.

\subsection{Research Prospects and Insufficiency}

The research on industrial policy and corporate tax avoidance in this article is an exploratory study. There may be some defects in the measurement of indicators and data selection. In the future research, improvement still needs to be made. The main problems and potential research directions in this paper include the following aspects:

The research in this article has some limitations. First of all, industrial policies are too numerous to include not only the five-year plan promulgated by the National Development and Reform Commission, but also a series of concrete industrial policies accompanied by the central government and local governments, which are limited by their capabilities. The main variables of this article are set only for the five-year plan. Second, the role of industrial policy, in addition to including listed companies, also includes a large number of non-listed companies, and we only studied the sample of China's A-share listed companies, and the scope of the sample is more one-sided. Finally, this paper attempts to use industrial divisions to connect individual industrial policies with individual micro-enterprises. However, because the purely manual method is used when organizing industrial policy data, it will inevitably cause some deviations.

This article examines industrial policies and corporate tax avoidance, and studies only three five-year plans. And simply set the measurement of industrial policy as a dummy variable, but did not express the support of the industrial policy and the specific expressions. In later studies, we can try to introduce concrete realizations of industrial policies, or try to study the impact of industrial policy inclinations on corporate tax avoidance; we can also introduce specific industrial policies introduced by various local governments to include local governments and the central government. The industrial policy is given a certain weight to study the impact of industrial policies on the tax avoidance of enterprises; it is also possible to further classify industrial policies. For example, some 
scholars classify them into industrial structure policies, industrial organization policies, industrial technology policies, and industrial space. With regard to the specific forms of expression such as the allocation of policies, the four major types of industrial policies have only a division of labor oriented and are closely related to one another.

As far as the implementation of industrial policies is concerned, we only consider the use of data on the level of corporate tax avoidance in the current period to analyze the role of industrial policies, but do not include the lagging effects of industrial policies in the scope of the study. According to past research, the implementation effect of policies often lags behind the time for policy formulation and promulgation. Therefore, in further studies, we can consider the lag effect of industrial policies. Further, it is also possible to divide industries into industries. The influence of the policy or lagging influence will be taken into consideration.

\section{References}

[1] Jiang, G.H. and Rao, P.G. (2011) Macroeconomic Policy and Micro-Corporate Behavior-Expanding the New Field of Accounting and Financial Research. Accounting Research, No. 3, 9-18.

[2] Bergström, F. (2000) Capital Subsidies and the Performance of Firms. Small Business Economics, 14, 183-193. https://doi.org/10.1023/A:1008133217594

[3] Aghion, P., Cai, J., Dewatripont, M., et al. (2015) Industrial Policy and Competition. American Economic Journal: Macroeconomics, 7, 1-32. https://doi.org/10.1257/mac.20120103

[4] Chen, D.H., Li, Z. and Xin, F. (2010) Industrial Policy and Corporate Financing: Empirical Evidence from China. International Symposium on Accounting and Financial Research in China, Shanghai, 4 December 2010, 281-360.

[5] Li, W.J. and Li, Y.T. (2014) Does Industrial Policy Inspire Companies? China Industrial Economy, No. 5, 122-134.

[6] Li, W.J. and Zheng, M.N. (2016) Substantive Innovation or Strategic Innovation?-Effect of Macro Industrial Policy on Micro-Enterprises Innovation. Economic Research, No. 4, 60-73.

[7] Han, Q. and Hong, Y.X. (2014) National Industrial Policy, Asset Price and Investor Behavior. Economic Research, No. 12, 143-158.

[8] Bi, X.F., Zhang, J.M. and Li, H.Y. (2015) Industrial Policy, Managerial Overconfidence, and Corporate Liquidity Risks. Accounting Research, No. 3, 57-63.

[9] Zhu, J.G., Han, F.C. and Lu, Z.F. (2015) Industrial Policy, Banking Relevance and Corporate Debt Financing: An Empirical Study Based on A-Share Listed Companies. Financial Research, No. 3, 176-191.

[10] Porcano, T.M. (1986) Corporate Tax Rates: Progressive, Proportional, or Regressive. Journal of the American Taxation Association, 7, 17-31.

[11] Wang, Y.T., Wang, L.L. and Gong, C.P. (2009) Income Tax Reform, Earnings Management and Economic Consequences. Economic Research, No. 3, 86-98.

[12] Li, Z.F. and Zheng, Y.H. (2010) Comparison of Earnings Management Methods for Tax Avoidance: Research on Accrued Project Manipulation and Real Activity Control. Finance and Economics Research, No. 6, 80-89.

[13] Defond, M.L. and Jiambalvo, J. (1994) Debt Covenant Violation and Manipulation 
of Accruals. Journal of Accounting \& Economics, 17, 145-176. https://doi.org/10.1016/0165-4101(94)90008-6

[14] Desai, M.A. and Dharmapala, D. (2005) Corporate Tax Avoidance and Firm Value. Review of Economics \& Statistics, 91, 537-546. https://doi.org/10.1162/rest.91.3.537

[15] Dyreng, S.D. and Lindsey, B.P. (2009) Using Financial Accounting Data to Examine the Effect of Foreign Operations Located in Tax Havens and Other Countries on U.S. Multinational Firms' Tax Rates. Journal of Accounting Research, 47, 1283-1316. https://doi.org/10.1111/j.1475-679X.2009.00346.x

[16] Edwards, A., Schwab, C. and Shevlin, T. (2016) Financial Constraints and Cash Tax Savings. The Accounting Review, 91, No. 3. https://doi.org/10.2308/accr-51282

[17] Cai, H. and Liu, Q. (2009) Competition and Corporate Tax Avoidance: Evidence from Chinese Industrial Firms. The Economic Journal, 119, 764-795. https://doi.org/10.1111/j.1468-0297.2009.02217.x

[18] Beck, T., Lin, C. and Yue, M. (2014) Why Do Firms Evade Taxes? The Role of Information Sharing and Financial Sector Outreach. The Journal of Finance, 69, 763-817. https://doi.org/10.1111/jofi.12123

[19] Crocker, K.J. and Slemrod, J. (2005) Corporate Tax Evasion with Agency Costs. Journal of Public Economics, 89, 1593-1610. https://doi.org/10.1016/j.jpubeco.2004.08.003

[20] Atwood, T.J., Drake, M.S., Myers, J.N., et al. (2010) Home Country Tax System Characteristics and Corporate Tax Avoidance: International Evidence. Accounting Review, 87, 1831-1860. https://doi.org/10.2308/accr-50222

[21] Fan, Z.Y. and Tian, B.B. (2013) Tax Competition, Tax Law Enforcement and Corporate Tax Avoidance. Economic Research, No. 9, 99-111.

[22] Wang, L.L. (2016) Impact of Financial Crisis, Financing Constraints, and Corporate Tax Avoidance. Nankai Business Review, 19, 155-168.

[23] Hanlon, M. and Slemrod, J. (2009) What Does Tax Aggressiveness Signal? Evidence from Stock Price Reactions to News about Tax Shelter Involvement. Journal of Public Economics, 93, 126-141. https://doi.org/10.1016/j.jpubeco.2008.09.004

[24] Slemrod, J. (2004) Are Corporate Tax Rates, or Countries, Converging? Journal of Public Economics, 88, 1169-1186. https://doi.org/10.1016/S0047-2727(03)00061-6

[25] Badertscher, B.A., Katz, S.P. and Rego, S.O. (2013) The Separation of Ownership and Control and Corporate Tax Avoidance. Journal of Accounting \& Economics, 56, 228-250. https://doi.org/10.1016/j.jacceco.2013.08.005

[26] Cai, H.B. and Rao, P.G. (2015) Institutional Investors, Tax Administration, and Corporate Tax Avoidance. Accounting Research, No. 10, 59-65.

[27] Ye, K.T. and Liu, X. (2011) Tax Collection, Income Tax Cost and Earnings Management. Management World, No. 5, 140-148.

[28] Mertens, J.B. (2003) Measuring Tax Effort in Central and Eastern Europe. Public Finance \& Management, 3, 530-563.

[29] Xu, W., Zeng, Y. and Zhang, J. (2011) Tax Enforcement as a Corporate Governance Mechanism: Empirical Evidence from China. Corporate Governance: An International Review, 19, 25-40. https://doi.org/10.1111/j.1467-8683.2010.00831.x 